\title{
Identification and Conformation of Bromadiolone Using HPLC and Molecular Dynamics Simulations
}

\author{
Munusamy Baskar ${ }^{1}$, Anju Devi $^{2}$, Bharti Arya ${ }^{3}$ \\ ${ }^{1,2,3}$ Central Forensic Science Laboratory, Directorate of Forensic Science Services, Bhopal-462030, India
}

\begin{abstract}
Rodenticides of warfarin group are mainly consisting of bromadiolone(3-(3-(4'-bromobiphenyl-4-yl)-3-hydroxy-1phenylpropyl)-4-hydroxycoumarin), 3-bromofuran, zinc phosphide etc., having different chemical composition which are frequently used for attempting suicide, perpetrating homicide, accidental inhalation of human being while baiting rats, birds, rabbits in agricultural fields. Bromadiolone, strong and long-acting rodenticide, having anticoagulant properties and also acting as antagonist by disrupting the normal blood clotting mechanisms to vitamin-K, required for blood clotting, and increasing the bleeding tendency in rodents has been taken for finding its reaction mechanisms with different solvent media. The main symptoms of the bromadiolone rodenticides are dizziness, unsteady gait, and abnormal behavior. In the present study, we focused to determine the presence of Bromadiolone in ppm level using HPLC, the reaction mechanism of functional groups (ketone, alcohol, phenol) present in the bromadiolone under the solvent media such as $\mathrm{H}_{2} \mathrm{O}$ and $\mathrm{HCl}$. The software, Avogadro, has been used to dynamically simulate the Bromadiolone for calculating its optimum energy and to conform the molecular structure under the influence of the water molecule. The reaction mechanism of functional groups in the bromadiolonecombined with the MD simulations may through light to reveal the enzymes activity in damaging the central nervous system which led to fatal.
\end{abstract}

KEYWORDS: Anticoagulant, Bromafuran, Bromadiolone, Rodenticides, Vitamin-K, Zincphosphide.

\section{INTRODUCTION}

Rats are among the most destructive type of pests, damaging crops and food material. Various classes of rodenticides having different chemical composition are available in India for killing these pests and among them, the most common compounds include zinc phosphide, bromafuran, bromethalin and bromadiolone. Zinc phosphide (3-[3-(4'-bromobiphenyl-4-yl)-3-hydroxy-1phenylpropyl]-4-hydroxycoumarine) usage are common and prevalently adopted for suicide, homicide, pest killing etc. The major difference between first-and second-generation anticoagulant rodenticides has been stated that the latter have longer body retention and therefore tend to lead to a longer period of bleeding. Trade names include Deadline, Lanirat, Maki, and SuperCaid. Bromadiolone is a white to off-white powder. It can be absorbed via the gastrointestinal tract, skin, and respiratory system. Due to having anticoagulant properties, it acts by disrupting the normal blood clotting mechanisms, causing an increased bleeding tendency in rodents. It acts as antagonist to vitamin-k, which is required for blood clotting. It act by binding to the enzyme vitamin $\mathrm{K} 2$, 3-epoxide reductase, thereby interrupting the cellular recycling of vitamin $\mathrm{K}$. The synthesis of vitamin $\mathrm{K} 2$, 3-epoxide reductase takes place in liver which become the main target of the Bromadiolone. Rat liver contains 1-2 mole of enzyme per gram tissue which is a 4-5-fold overcapacity for maintaining effective vitamin K recycling. Its bioavailability is approximately $50 \%$ and the minimum plasma concentration is reached approximately 6-9 hr. after ingestion and when ingested with High dose partial thromboplastin times exceed up to 9 weeks 2 .

Symptoms of acute intoxication by anticoagulant rodenticides range from increased bleeding tendency in minor or moderate poisoning to massive hemorrhage in more severe cases. The signs of poisoning develop with a delay of one to several days after absorption. Warfarin is associated in humans with the induction of developmental malformations when taken as a therapeutic agent during pregnancy. No cases of developmental defects following the use of anticoagulants as rodenticides have been reported ${ }^{1}$. In case of no active bleeding and INR (International Normalized Ratio) is $\leq 4.0$, as a routine measurement for measuring anticoagulant rodenticides, treatment with Phytomenadione is not required and no bleeding or only minor bleeding and also the INR $\geq 4.0$, the treatment with $10 \mathrm{mg}$ of Phytomenadione should be administered by slow intravenous injection ${ }^{3}$. The sex specific variations in response towards toxicity of bromadiolone that the female rats were found more tolerant than the male 


\section{International Journal of Current Science Research and Review}

ISSN: 2581-8341

Volume 04 Issue 10 October 2021

DOI: 10.47191/ijcsrr/V4-i10-30, Impact Factor: 5.825

ratshave also been reported ${ }^{4}$. The slow disappearance of the Bromadiolone from plasma and high solubility in lipids has been reported from a study of case report in-vivo ${ }^{5}$.

The pharmacokinetics of eight anticoagulant rodenticides in plasma and liver of the mouse was investigated ${ }^{6}$ after a single oral administration of one half the lethal dose 50 (LD50) and concluded that the anticoagulant rodenticides are accumulating in the liver resulting in high liver concentrations for a prolonged period oftime and in plasma, the concentrations tend to decreaserapidly which makes it more difficult to use this matrix asdiagnostic material in malicious poisoning cases of companion animals. In sheep, warfarin, chlorophacinone, and bromadiolone were not degraded in the rumen but their bio availabilities were high after oral administration and the kinetics of these compounds in sheep and other mammals arequite similar. These data suggest that the lack of susceptibility of ruminants to these anticoagulantrodenticides cannot be explained by either ruminaldegradation or the specific toxicokinetic of the semantic coagulants ${ }^{7}$. Strategies of anticoagulation during and after pregnancy offering warfarin would be the best thromboplast in protection to the mother. However, it carries higher risk of fetus loss and complication since the warfarin crosses the placenta has been reviewed ${ }^{8}$.The ingested super warfarin compounds listedhave been identified using HPLC and GCMS in the case report of clinical trial ${ }^{9}$.Bromadiolone has also been declared as a potential pesticide in place of warfarin and other anticoagulant which required repeated feeding to kill rodents ${ }^{10}$. Second generation anticoagulant in blood of dogs poisoned after an accidental intake was detected by using HPLC ${ }^{11}$. The deposition of Swarfarin and R-warfarin by collecting citrated blood from normal cats were analyzed using ELISA testing. The $\mathrm{S}$ isomer is markedly more potent as a vitamin $\mathrm{K}$ antagonist than the $\mathrm{R}$ isomer in humans ${ }^{12}$.

A case study of which the super warfarin poisoning due to chronic repetitive occupational dermal exposure to commercial rodenticide has been presented using LC-MS-MS ${ }^{13}$. Toxicity to human being with rodenticide poisoning was also examined ${ }^{14}$ the records of 20 patients with rodenticide poisoning among which 12 were related to Bromadiolone and 8 Brodifacoum rodenticides. The trace level detection of Bromadiolone and Brodifocoum in whole blood sample of human being has been carried out with a lower limit of detection of 0.1 and $0.2 \mathrm{ng} / \mathrm{mL}$ using the LC-ESI/MS/MS ${ }^{15}$. The concentration of $30 \mu \mathrm{g} / \mathrm{mL}$ and 0.98 $\mu \mathrm{g} / \mathrm{mL}$ of two superwarfarins, Bromadioloneand brodifacoum, respectively were detected by Liquid Chromatography (LC) in the investigation of warfarin and superwarfarins (Bromadiolone, Difenacoum and Brodifacoum) in the serum ${ }^{16}$.

A rapid and sensitive high-performance liquid chromatography tandem mass spectrometric method (HPLC/MS-MS) has been employed and validated for the determination of bromadiolone extracted from the whole blood by liquid-liquid extraction with ethyl acetate using warfarin as an internal standard (IS $)^{17}$.A method for Quantification of bromadiolone in whole blood using liquid-chromatography-mass spectrometry (LC-MS) was developed and estimated the half-life and the ratio of plasma/blood in bromadiolone as $1.7+/-0.6$ respectively ${ }^{18}$. Forensic purpose of identifying the time of ingestion of two anticoagulant rodenticides, Bromadiolone and brodifacoum, have been established from the liquid-liquid extraction of pulverized hair sample using the liquid chromatography (LC) ${ }^{19}$. High Performance Liquid Chromatography (HPLC) was employed for the determination of bromadiolone residues in hen's eggs and its plasma and reported that the bromadiolone treated with 10 and60 mg/kg was not dete 4 ted in albumen but was present in yolk ${ }^{20}$. The extract of baits containing bromadiolone, brodifacoum and difenacoum, using hexaneacetonitrile have been examined using reversed phase HPLC and recommended in determination of brodifacoum, bromadiolone and difenacoum as they have been recovered as $94 \%, 98 \%$ and $90 \%$ respectively ${ }^{21}$.

\section{MATERIALS AND METHODS}

The standard sample of bromadiolone was received from Central Insecticide laboratory, Faridabad, Government of India, Ministry of Agriculture \&Farmers Welfare, Department of Agriculture, Cooperation \&Farmers Welfare Directorate of Plant Protection, Quarantine \&Storage for the purpose of this study. Thus, the portion of the sample i.e., 10mg was dissolved in the concentrated $\mathrm{HCl}(10 \mathrm{ml})$ and observed the formation of the white precipitate which indicates the reaction between the possible hydroxyl functional groups possessed in the molecular structure. The sample was also dissolved in water. However, the sample was not fully dissolved in the solvent. The functional groups are making hydrogen bonds with the water molecule. 


\section{International Journal of Current Science Research and Review}

ISSN: 2581-8341

Volume 04 Issue 10 October 2021

DOI: 10.47191/ijesrr/V4-i10-30, Impact Factor: 5.825

IJCSRR@ 2021

www.ijesrr.org

HPLC

High Performance Liquid Chromatography (HPLC) was used for the identification of Bromadiolone in the ppm level.

Column : Hypersil ODS2 C18

Size : $250 \times 4.6 \mathrm{~mm}$

Mobile Phase : $\quad \mathrm{MeOH}: \mathrm{H} 2 \mathrm{O}=85: 15$

Detection : DAD :4.6 mm

Injection : $\quad 20 \mu 1$

Pressure : $10.0 \mathrm{MPa}: 250 \mathrm{~mm}$

Flowrate : $1.0 \mathrm{ml} / \mathrm{min}$

\section{Experimental Conditions}

HPLC equipped with Hypersil 0DS2 C-18 column(length 250mm X Diameter 4.6mm), D-3335i DAD detector, P3000, binary gradient system, make- Analytical Technologies. High performance liquid chromatography is a type of chromatography technique that pumps a sample analyte in a solvent (mobile phase) at high pressure through a column. Elution was performed using mobile phase methanol: water (85:15). Sample was loaded manually using $20 \mu 1$ syringe. Before performing the sample run, a blank sample was performed to validate the method so as to check any impurity adheres in the column using same solvent system. The method for floating the ratio of the methanol: water (85:15) was already set to perform the elution at the flow rate of $1.0 \mathrm{ml} / \mathrm{min}$. Retention time of the peak was observed at 1.97-minute10ppm sample of bromadiolone was prepared. The results of the identification of the bromadiolone is as given in the spectrum.

\section{Molecular Dynamics}

The pdb file of bromadiolone was collected from National Library of Medicine (NLM). This pdb file was auto optimized under steepest descent minimization algorithm using the Universal Force Field *UFF), General Amber Force Field (GAFF), Merck Molecular Force Field (MMFF94)and MMFF94s, where 's' stands for static, respectively. The results and the finalized molecular structure of the bromadiolone are as represented in the Figure $3 \mathrm{a}, 3 \mathrm{~b}, 3 \mathrm{c}$ and $3 \mathrm{~d}$. The molecular structure of Bromadiolone obtained by optimizing the molecule with the help of GAFF is highly recommended as the potential energy of the molecule is stabilized at 118.7126 calories as compared to the potential energies, $394.259 \mathrm{cal}, 403.006 \mathrm{cal}$. and $372.926 \mathrm{cal}$., of all the other force field employed for modelling in this study as shown in table 2.

The orientation of the bromadiolone optimized on applying various force field is some what unlike of each other as it shows the variation on the flanking phenyl group at the center of the molecule which could only be due to the near interaction between the $\mathrm{C}-\mathrm{H}$ and $\mathrm{C}=\mathrm{O}$ of 1-benzopyran-2-one.The distance between $-\mathrm{H} \cdots \mathrm{C}=$ is $2.655 \AA$. The structure of Bromadiolone obtained by using GAFF is varying from other conformations, thus, obtained by using other three force fields.

In the above cyclic reaction, conversion of vitamin KH2 (Hydroxyquinone) to Vitamin k epoxide occur by carboxylation reaction in the presence of enzyme as a catalyst i.e., $\gamma$-glutamylcarboxylase. Further Vitamin k epoxide is converted in to vitamin $\mathrm{K}$ quinone by Vitamin k epoxide reductase (VKOR) as shown in Figure 4. In the same manner, the reaction mechanism of SN1 with $\mathrm{HCl}$ and with $\mathrm{H}_{2} \mathrm{O}$ is also shown in figure 5 and 6 respectively.

The moiety of water molecule instead making a hydrogen bond with the Oxygen of the alcohol bonded with Hydrogen.

\section{RESULTS AND DISCUSSIONS}

This work was divided in to two parts of which one is the reaction mechanism with $\mathrm{HCl}$ and $\mathrm{H}_{2} \mathrm{O}$ and the other is that the molecule was subjected in to molecular dynamics simulation with the help of Avogadro software ${ }^{22}$. The detection of Bromadiolone down to 10ppm level using the HPLC technique as indicated in the figure 2.The structure conformations of Bromadiolone is considerably deviating, while using various force field in the Molecular Dynamics treatment, from the given original orientation, in the figure 1a, of Bromadiolone as given in the table 1. The optimized conformation of Bromadiolone in the Figure $3 \mathrm{a}$ under the optimization of GAFF is the unique from other three force field as highly stabilized at potential energy of 118.7126 calories. Hence, this conformation is favorable for Bromadiolone at $300^{\circ} \mathrm{C}$. 


\section{International Journal of Current Science Research and Review}

ISSN: 2581-8341

Volume 04 Issue 10 October 2021

DOI: 10.47191/ijcsrr/V4-i10-30, Impact Factor: 5.825

IJCSRR@ 2021

WwW.ijcsrr.org

\section{CONCLUSION}

Rodenticides are vastly used in agricultural as well as in household to get rid of rodents. From the study in the field of Rodenticides, it has been observed that the use of the same for homicidal and suicidal purposes has been increased. As these are becoming potential tools of either homicide or suicide, it is necessary to understand the reaction mechanism of these rodenticides into physiological conditions for pharmaceutical finding to find out the correct therapeutic use in the case of saving human life. In the present study it was carried out how these could react within the presence of acid and water. This can be further related with the acid present inside stomach. Possible standard reaction mechanism has been illustrated in this study. The possible reaction with water also carried out and reaction for the same was also illustrated. This study can be beneficial for study physiological impact of bromadiolone and can also be used to understand the possible reaction as well as how the optimized conformation of Bromadiolone is stabilized while reacting with water molecules. It has been observed that the option and possible way of identification of Bromadiolone will only be with the help of HPLC.

\section{ACKNOWLEDGEMENT}

The authors acknowledge Ms. Bharti Arya, Dy. Director (Chem) of CFSL, Bhopal to have provided the reference sample of Bromadiolone received from the Central Insecticide laboratory, Faridabad, Government of India, Ministry of Agriculture \&Farmers Welfare, Department of Agriculture, Cooperation \&Farmers Welfare Directorate of Plant Protection, Quarantine $\&$ Storage for the purpose of this study.

\section{REFERENCES}

1. Wang M, Yang Y, Hou Y, Ma W, Jia R, Chen J (2017).Effects of bromadiolone poisoning on the central nervous system. Neuropsychiatric Dis Treat. 13: 2297-2300. doi: 10.2147/NDT.S142375

2. Revathi K and Yogananda M (2006). Effect of bromadiolone on hematology, liver andkidney in Musmusculus. Journal of EnvironmentalBiology, 27(1): 135-40. www.jeb.co.in

3. Barbara E Watt, Alex T Proudfoot, Sally M Bradberry, J Allister Vale (2005). Anticoagulants rodenticides, 24(4):259269. DOI: 10.2165/00139709-200524040-00005

4. Nancy Garg and NeenaSingla(2014). Toxicity of Second Generation Anticoagulant Bromadiolone AgainstRattusRattus: Individual and Sex Specific Variations. CIB Tech, Journal of Zoology ISSN: 2319-3883 (Online) An Open Access, Online International Journal, 3(2), 43-48. http://www.cibtech.org/cjz.htm.

5. Chow EY, Haley LP, Vickars LM, Murphy MJ (1992). A case of bromadiolone (superwarfarin) ingestion. CMAJ, 147(1):60-62. PMID: 1393889; PMCID: PMC1336120

6. Vandenbroucke, V., Bousquet-Melou, A., De Backer, P., Croubels, S (2008). Pharmacokinetics of eight anticoagulant rodenticides in mice after single oral administration. J. vet. Pharmacol. Therap. 31, 437-445. DOI 10.1111/j.1365-2885.2008.00979. x.

7. Berny, P. J. de Oliveira, L. A. Videmann, B. Rossi, S (2006). Assessment of ruminal degradation, oral bioavailability, and toxic effects of anticoagulant rodenticides in sheep. Am. J. Vet. Res. 2006. doi: 10.2460/ajvr.67.2.363.

8. Alshawabkeh L, Katherine E, Valente A.M (2016). Anticoagulation during pregnancy: evolving strategies with a focus on mechanical valves. J AmCollCardiol, 68(16):1804-1813. doi: 10.1016/j.jacc.2016.06.076.

9. Routh C.R., Douglas, D.A., Triplett D.A., Murphy M.J., Felice L.J.,Sadowski J.A., Ted BovillE.G (1991). American Journal of Hematology 3650-54 (1991). https://doi.org/10.1002/ajh.2830360111

10. Meehan, A. P(1978). RodenticidalActivity of Bromadiolone - A New Anticoagulant: Proceedings of the 8th Vertebrate Pest Conference, University of Nebraska-Lincoln. https://digitalcommons.unl.edu/vpc8/31.

11. RobbenJ.H., KuijpersE.A.P \&MoutH.C.A (2011). Plasma superwarfarin levels and vitamin K1 treatment in dogs with anticoagulant rodenticide poisoning. DOI 10.1080/01652176.1998.9694831.

12. Smith, S.A., Kraft, S.L, Lewis, D.C., Freeman, L.C (2000). Plasma pharmokinetics of warfarin enantiomers in cats. J.Vet. Pharmacol. Ther., 23: 329-337. DOI 10.1111/j.1365-2885.2000.00269.x 


\section{International Journal of Current Science Research and Review}

ISSN: 2581-8341

Volume 04 Issue 10 October 2021

DOI: 10.47191/ijesrr/V4-i10-30, Impact Factor: 5.825

IJCSRR@ 2021

www.ijesrr.org

13. Ozdemir Z.N, SahinU,BeksacM,A. (2016). A Case of Superwarfarin Poisoning Due to Repetitive Occupational Dermal Rodenticide Exposure in a worker. Turkish journal of hematology, 33(3):251-253. Forensic SciInt.222(1-3)313-317. DOI: $10.4274 /$ tjh.2015.0433.

14. Hui Yan, Ping Xiang, Lin Zhu, Min Shen (2012). Determination of bromadiolone and brodifacoum in human blood using LC-ESI/MS/MS and its application in four superwarfarin poisoning cases. DOI: 10.1016/j.forsciint.2012.07.008.

15. Hsin-Ying Yu, Ja-Liang Lin, Jen-Fen Fu, Jui-Hsiang Lin, Shou-Hsuan Liu, Cheng-HaoWeng, Wen-Hung Huang, KuanHsing Chen, Ching-Wei Hsu, and Tzung-Hai Yen (2013). Outcomes of patients with rodenticide poisoning at a far east poison center. Springerplus. 2: 505. doi: 10.1186/2193-1801-2-505.

16. Xuejie Chen, Da-Yun Jin, Darrel W Stafford, Jian-Ke Tie (2018). Evaluation of oral anticoagulants with vitamin K epoxide reductase in its native milieu. Blood, 132(18):1974-1984. DOI: 10.1182/blood-2018-05-846592

17. Mi-Cong Jin, Yi-Ping Ren, Xiao-Min Xu, Xiao-Hong Che(2007). Determination of bromadiolone in whole blood by high-performance liquid chromatography coupled with electrospray ionization tandem mass spectrometry. Forensic Sci Int. 171(1)52-56. DOI: 10.1016/j.forsciint.2006.10.005

18. Vindenes V, Karinen R, Hasvold I, Bernard J P, Morland J G, Chrisophersen AS (2008). Bromadiolone poisoning: LCMS method and pharmacokinetic data. J Forensic Sci., 53(4),993-996. DOI: 10.1111/j.1556-4029.2008.00737. x.

19. Lin Zhu, Hui Yan, BaohuaShen, Yan Shi, Min Shen, Ping Xiang (2013). Determination of bromadiolone and brodifacoum inhuman hair by liquid chromatography/tandem mass spectrometry andits application to poisoning cases.Rapid Commun Mass Spectrom., 27(4), 513-520. doi: 10.1002/rcm.6477

20. Mario Giorgi and GraziaMengozzi (2010). An HPLC method for the determination of bromadiolone plasma kinetics andits residues in hen eggs. Journal of Chromatographic science, 48(9), 714-720. DOI: 10.1093/chromsci/48.9.714

21. Belyaev, E.S., Andreev, S.V., Ivanova, A.O, Ischenko, A.A (2019). Determination of brodifacoum, bromadiolone and difenacoum in commercial rodenticides by using high-performance liquid chromatography with UV detection. Bulgarian Chemical Communication, D51, 47-51. ISSN: 0324-1130, WWW.BCC.BAS.BG

22. Marcus D Hanwell, Donald E Curtis, David C Lonie, Tim Vandermeersch, Eva Zurek and Geoffrey R Hutchison (2012). "Avogadro: An advanced semantic chemical editor, visualization, and analysis platform". Journal of Cheminformatics, 4:17. http://avogadro.cc/.

Table 1. The details of the HPLC spectrum of $10 \mathrm{ppm}$ Bromadiolone

\begin{tabular}{|l|l|c|l|l|l|}
\hline Name & $\begin{array}{l}\text { Start } \\
\text { Time(min) }\end{array}$ & Ret. Time(min) & $\begin{array}{l}\text { Peak } \\
\text { Height(mv) }\end{array}$ & End Time(min) & $\begin{array}{l}\text { Peak } \\
\text { Width(min) }\end{array}$ \\
\hline Bromadiolone & 1.71 & 1.97000 & 115.69 & 2.41 & 0.22 \\
\hline
\end{tabular}

Table 2. Conformations of Bromadiolone in various force field

\begin{tabular}{|l|l|l|l|}
\hline S.No. & Force Field & Algorithm used & Energy in Calories \\
\hline 1 & GAFF & \multirow{2}{*}{ Steepest Descent } & 118.7126 \\
\cline { 1 - 1 } 2 & MMFF94 & & 394.259 \\
\cline { 1 - 1 } 3 & MMFF94s & & 403.006 \\
\hline 4 & UFF & & 372.926 \\
\hline
\end{tabular}




\section{International Journal of Current Science Research and Review}

ISSN: 2581-8341

Volume 04 Issue 10 October 2021

DOI: 10.47191/ijesrr/V4-i10-30, Impact Factor: 5.825

IJCSRR@ 2021

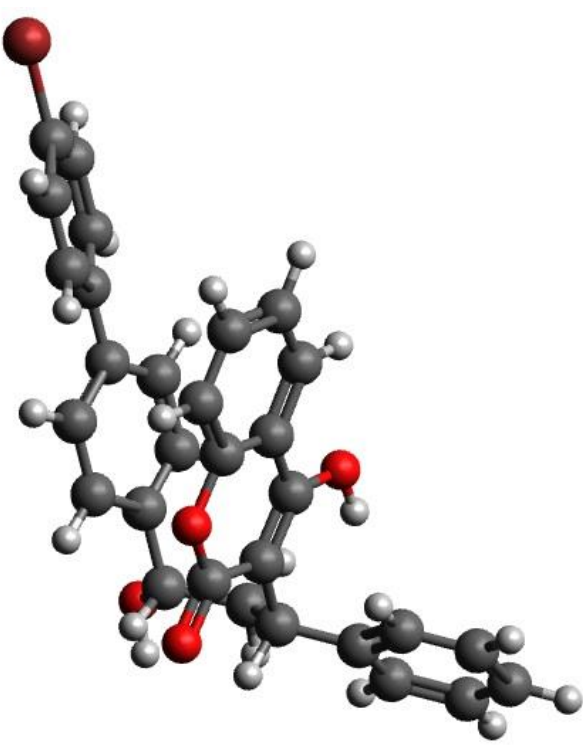

(a)

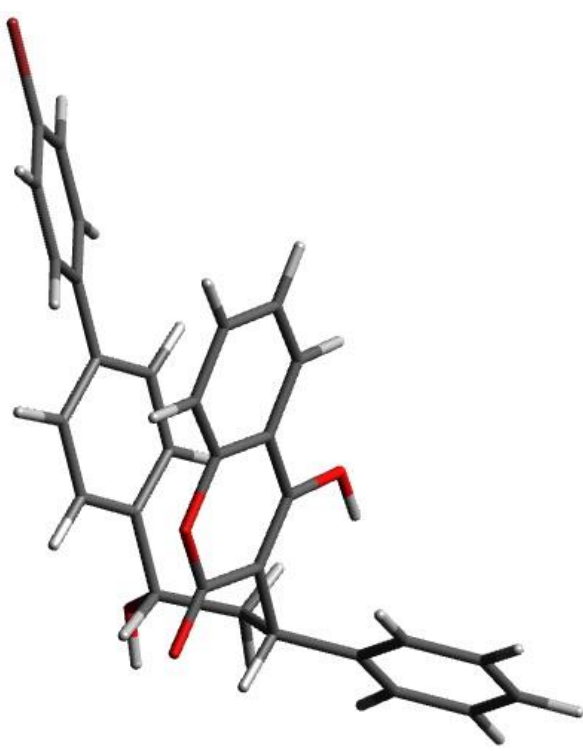

(b)

Figure 1: (a) Ball and stick and (b) wireframe model of primary bromadiolone

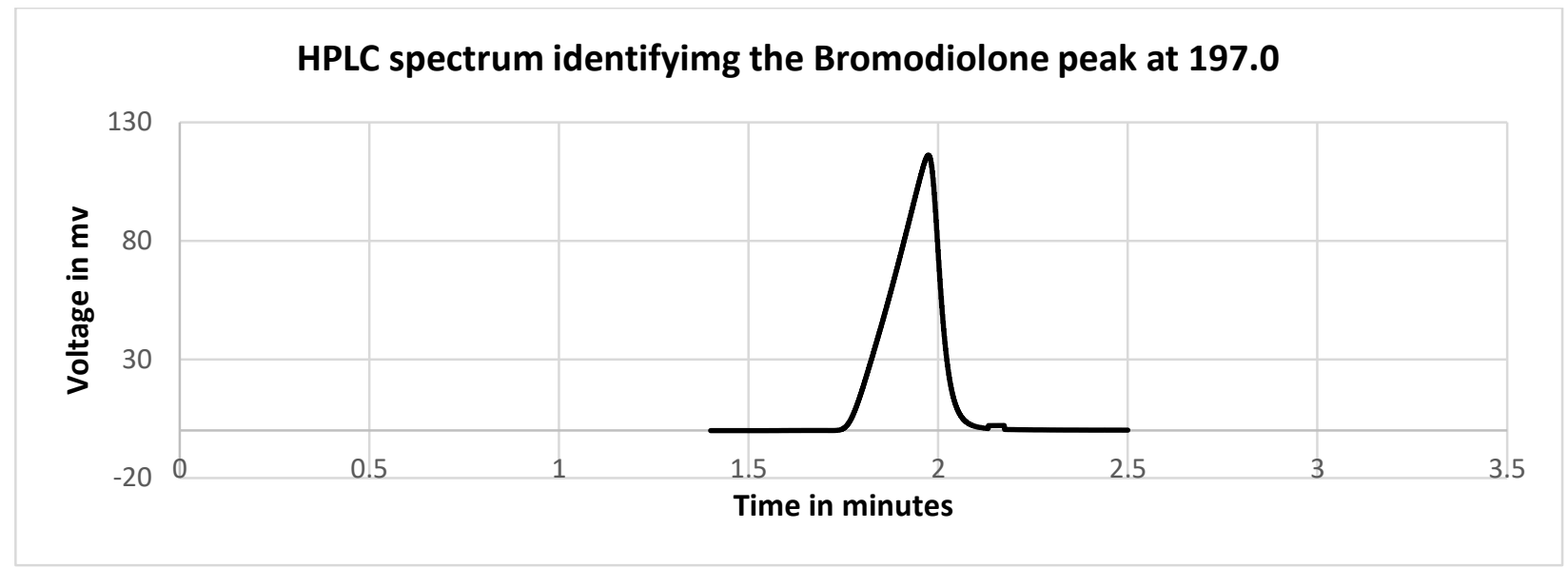

Figure 2: HPLC spectrum identifying the Bromadiolone peak at 115.69

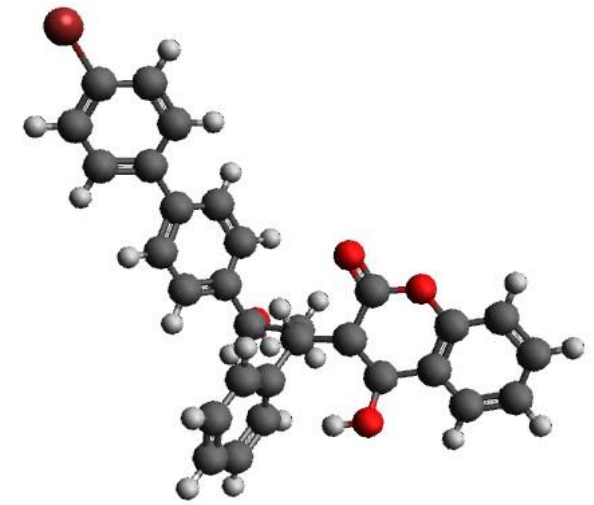

Figure 3a: Conformations of Bromadioloneoptimized with GAFFforce field. 
International Journal of Current Science Research and Review

ISSN: 2581-8341

Volume 04 Issue 10 October 2021

DOI: 10.47191/ijcsrr/V4-i10-30, Impact Factor: 5.825

IJCSRR@ 2021

www.ijesrr.org

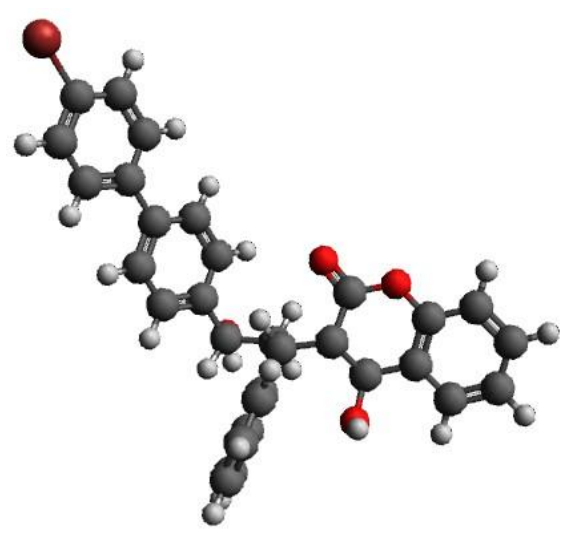

Figure 3b: Conformations of Bromadioloneoptimized with MMFF94force field.

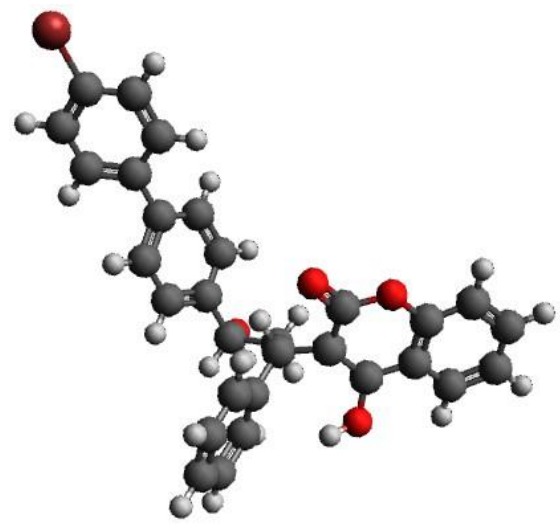

Figure 3c: Conformations of Bromadioloneoptimized with MMFF94sforce field.

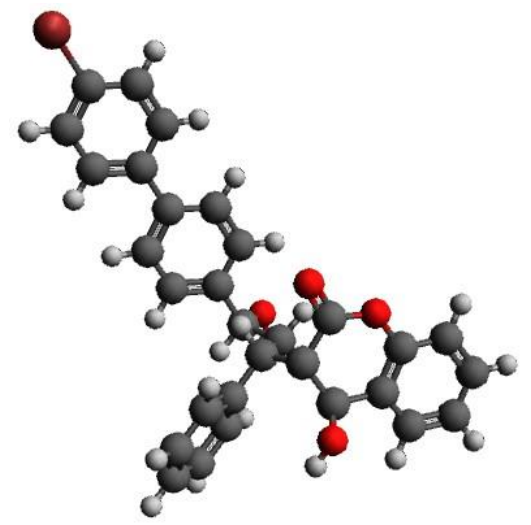

Figure 3d: Conformations of Bromadioloneoptimized with UFF force field. 


\section{International Journal of Current Science Research and Review}

ISSN: 2581-8341

Volume 04 Issue 10 October 2021

DOI: 10.47191/ijesrr/V4-i10-30, Impact Factor: 5.825

IJCSRR@ 2021

Reaction Mechanism with Vitamin K cycle

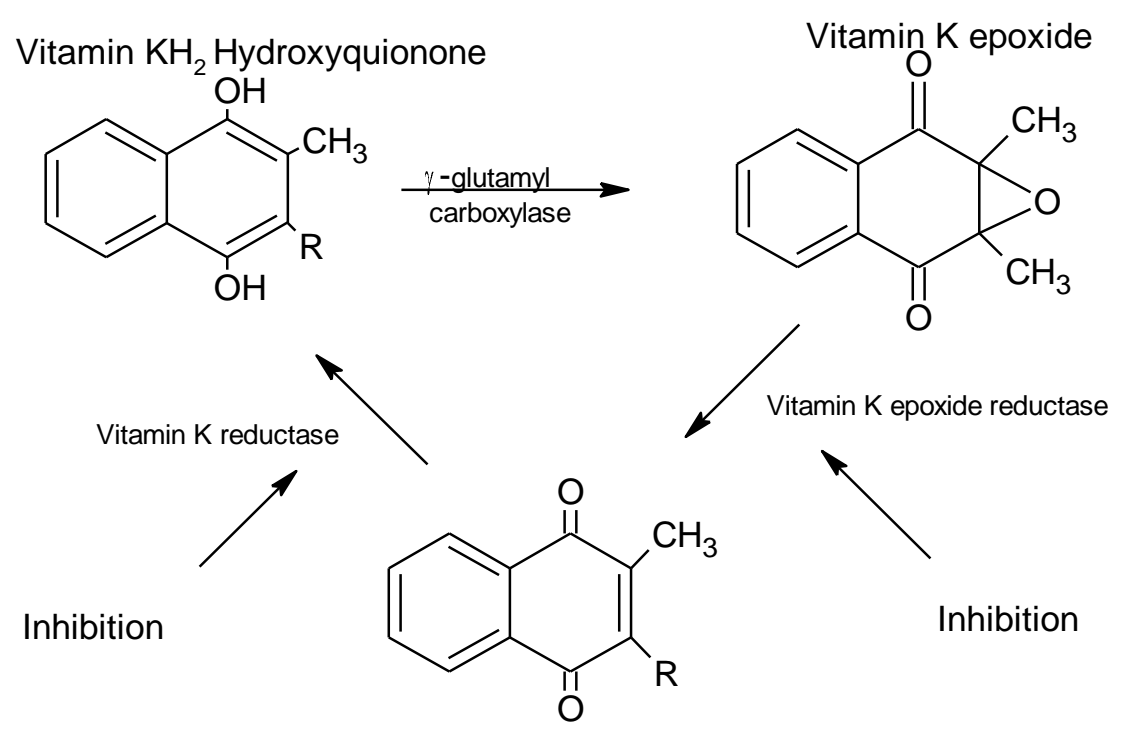

Vitamin K Quinone

Figure 4: Molecular structure of the compounds and their warfarin

SN1 reaction with $\mathrm{HCl}$<smiles>O=C1c2ccccc2OC(O)C1C(CC(O)c1ccc(-c2ccc(Br)cc2)cc1)c1ccc2c(c1)OC(O)C(C(CC(Cl)c1ccc(-c3ccc(Br)cc3)cc1)c1ccccc1)C2=O</smiles>

Figure 5: Results of SN1 reaction with $\mathrm{HCl}$

Reaction with $\mathrm{H}_{2} \mathrm{O}$<smiles>O=C1c2ccccc2OC(O)C1C(CC(O)c1ccc(-c2ccc(Br)cc2)cc1)c1ccc(O)cc1</smiles>

Figure 6: Results of SN1 reaction with $\mathrm{H}_{2} \mathrm{O}$

Cite this Article: Munusamy Baskar, Anju Devi, Bharti Arya (2021). Identification and Conformation of Bromadiolone Using HPLC and Molecular Dynamics Simulations. International Journal of Current Science Research and Review, 4(10), 14571464 